\title{
Technical Analysis and Stock Price Prediction? Evidence from Malaysian Stock Market
}

\author{
Kelvin Lee Yong Ming, Mohamad Jais and Bakri Abdul Karim \\ Faculty of Economics and Business, Universiti Malaysia Sarawak (UNIMAS)
}

\begin{abstract}
This study aims to examine the ability of technical analysis in predicting the stock price and generating profits. Two of the technical analysis indicators, which are (i) Variable Moving Average (VMA) and (ii) Elliot Wave Principle incorporated (Fibonacci numbers) are utilized in this study. In addition, this study also examines the relationship between the signals emitted by VMA and the stock returns. This study uses daily data of 569 stocks listed in the main market of Bursa Malaysia from 2005 to 2012. The empirical findings indicate that the VMA are useful technical indicator in analysing the medium capitalization stocks. This result is further supported using the sub-sample and out-of-sample test. Moreover, the signals emitted via VMA rules are found to be significant influencing the stock returns. Furthermore, the results also show that the Elliot Wave Principle (Fibonacci numbers) is found to be significant influencing the stock price movements of large capitalization stocks. The results of this study have a significant implication towards investors and technical analysts.
\end{abstract}

Keywords: Elliot wave, Fibonacci sequences, Moving average, Technical analysis,

\section{INTRODUCTION}

Since the establishment of Dow Theory in 1900, technical analysis has gained interest among practitioners, researchers and academicians. Technical analysis is a common heading for a wide range of trading techniques or strategies (Brock, Lakonishok \& LeBaron, 1992). Each of the technical trading rules under the roof of technical analysis follow the common philosophy that future stock prices can be predicted using past stock prices (McKenzie, 2007). Technical analysis was first introduced at the early 1700s. The legendary Japanese rice trader, Munehisa Homma was the first person who predicted the future price movement using the past prices in the Dojima Rice Exchange in Osaka (Nison, 2001, p.15). The trading techniques applied by Homma also evolved into the candlestick chart. The influential studies of Brock et al. (1992) and Bessembinder and Chan (1995) revealed that technical trading rules do have the ability to generate profit in stock market. However, if the price movements are forth putting profitably by way of technical analysis, it is against the Efficient Market Hypothesis (EMH) established by Fama (1970).

Even though it has been widely applied, the technical analysis remains a puzzle among the researchers. Zhu and Zhou (2009) had pointed out three reasons to further explain the arguments. Firstly, there was no theoretical basis exists for the technical analysis. Second, earlier studies found that the technical analysis cannot bring any profits as the earlier studies assumed the random walk model for stock prices. Third, there were mixed and inconclusive empirical findings presented by the previous studies. Therefore, this issue is still open for further empirical examination. In the context of Malaysia, studies on this issue are rather limited. Thus, this paper aims to examine the ability of technical indicators which are Variable Moving Average (VMA) and Elliot Wave Theory incorporated with Fibonacci numbers in predicting the movement of stock prices in Malaysia. We hope to contribute further to the body knowledge on this subject matter. The results of this study have major implications towards both investors and practitioners. The rest of this paper is organized as follows. In the next section, we discuss literature review. Methodology is presented 
in the third section. Section 4 provides empirical findings and discussion. Concluding remarks and implications of study are presented in the last section.

\section{LITERATURE REVIEW}

As mentioned by the prior study of Brock et al. (1992), technical analysis is a tool to forecast future prices by studying the past prices and a number of related security trading statistics. Isakov and Hollistein (1999) stated that technical analysis has been looked by the academics with contempt, as it contradicts one of the basic principles of financial theory: the weak-form efficient market hypothesis. Alexander (1961), the pioneer of filter rules application, found that the stock market was not following the random walk. The Alexander filter rules was also applied by Fama and Blume (1966) in their study, and they found that the techniques cannot outperform the buyand-hold policy.

Moving average is one of simplest and widely used technical analysis tools in the technical analysis literature. As a pioneer in the application of moving average, James (1968) pointed that the rationale behind moving average is simple, as the signals of uptrend (downtrend) security's price movements could be initiated when the present security's price move above (below) the level that was achieved in the past. As an impetus study, Brock et al. (1992) investigated two of the simplest technical trading rules, namely; moving average and trading-range breaks on a pretty long time series of Dow Jones Industrial Average (DJIA) from 1897 to 1986. The results of variable moving average was intriguing and showed that the returns generated by the buy and sell signals were 12 percent annually and -7 percent annually respectively. Hence, strong evidence has been provided to show that technical rules do own the predictive power.

In a later study, Bessembinder and Chan (1998) attempted to confirm the results of Brock et al. (1992) by using a more recent sample period (1926-1991) on the same sample. Bessembinder and Chan (1998) proposed that predictive power of the technical trading rules may be partially attributable to the return measurement errors arising from the nonsynchronous trading. Ready (2002) also updated the sample period of Brock et al. (1992), for the period of 1987 to 2000. Ready (2002) revealed that the technical trading rules that performed well in the study of Brock et al. (1992) did poorly in the recent years, where the average buy-sell differential was found to be negative for the recent years (1987-2000). Besides that, Lebaron (2000) who extended the sample period of Brock et al. (1992) found that the results had changed dramatically during the most recent period and suggested that it might be caused by technological change, better price information, lower transaction costs or the more attention paid to the technical trading rules. In spite of the contradictions to the study of Brock et al. (1992), it remains an impetus in the study of technical trading rules. The moving average rules of Brock et al. (1992) have been replicated by many later studies, such as; Ahmed, Beck and Goldreyer (2000); Bessembinder and Chan (1998); Campbell (2011); Detry and Grégoire (2001); Hudson, Dempsey and Keasey (1996); Lam, Yeung and Cheung (2007); Lubnau and Todorova (2014); Mills (1997); Ratner \& Leal (1999).

Hudson et al. (1996) and Mills (1997) tested the Brock et al. (1992) technical trading rules on the UK data, namely; the Financial Times Industrial Ordinary Index (FT 30) for the same period from July 1935 to January 1994. Results obtained by Hudson et al. (1996) support the evidence of technical trading rules possessing predictive power. On the contrary, the technical trading rules cannot generate excess return over the buy-and-hold strategy in the presence of transaction costs. They revealed that average excess return per round trip transaction was approximately $0.8 \%$, which could not be used to cover the $1 \%$ of round trip transaction costs charged. Although transaction costs were not considered in a study by Mills (1997), the study 
revealed that technical trading rules work well to beat buy-and-hold strategy in the earlier subperiods (1935-1954 and 1955-1974), but not in the later sub-period (1975-1994). These findings led Mills (1997) to conclude that the buy-and-hold strategy had clearly dominated the UK market over the study period of twenty years.

Using the stock price indices of the Asian stock market over the period 1975-1991, Bessembinder and Chan (1995) re-examined the technical trading rules of Brock et al. (1992). Bessembinder and Chan (1995) found that technical trading rules have stronger predictive ability in the emerging market (Malaysia, Thailand and Taiwan); but less predictive ability in the more developed market (Japan, Hong Kong and South Korea). Despite the slight difference in predictive ability across the Asian countries, the researchers still concluded that the Asian stock market is informational inefficient. It is noteworthy that the U.S market was also found to influence the forecasting of returns in Asian market. Lastly, the researcher found that the additional returns generated by technical trading rules would vanish when the round trip transaction costs exceed $1.57 \%$. A later study by Ratner and Leal (1999) presented evidence to support that Taiwan and Thailand were the Asian market where technical trading rules could be applied to generate profits. Meanwhile, Mexico was found to be the only one from the Latin market to show profitability with the application of technical trading rules.

Glezakos and Mylonas (2003) conducted their study by applied only the Moving Average rules on both the Athens Stock Exchange (emerging market) and Frankfurt Stock Exchange (developed market). Their findings indicate that moving average rules still possess the predictive power in the presence of transaction costs. Lam et al. (2007) and Campbell (2011) acknowledged that the profitability of technical trading rules of Brock et al. (1992) increase with the decrease in the length of moving average applied. Generally, the moving average rules have higher predictive power in emerging market than the developed market. In the Jordanian stock market, Muhannad A. Atmeh and Ian M. Dobbs (2006) and Abbad, Fardousi and Abbad (2014) analyzed the performance of moving average rules on the daily general index of Amman Stock Market, covering the period from 1992 to 2001 and 2000 to 2007, respectively. Even though most of the moving average rules were found to be not working, some shorter term rules [notably the $(1,5)$ moving average rules] still generated excess return in the presence of transaction costs. This is consistent with the finding of Isakov and Hollistein (1999) who realized that the $(1,5)$ was the best trading rules. However, Muhannad A. Atmeh and Ian M. Dobbs (2006) also suggested that the trading rules are not only useful for predicting market movements, as they can also be used to figure out the "profit improving" trading strategies. On a similar note, a later study by Abbad et al. (2014) showed that technical analysis has the predictive power on the stock price movement over the more recent period.

In Malaysia, the random walk hypotheses and the predictive power of the technical trading rules had both been tested by Lai, Balachandler and Nor (2007), based on the daily data of the Kuala Lumpur Stock Exchange Composite Index (KLSE CI) from 3rd January 1977 to 31st December 1999. The sample periods used in their study included both bullish and bearish periods. In their study, the random walk hypothesis was tested by using the variance ratio test; while the predictive power of technical trading rules was tested by using only the moving average rules. The researchers found that the KLSE CI followed a random walk during a bearish period. The results also indicated that the Variable Moving Average (VMA) rule and Fixed Moving Average (FMA) rule, particularly the ones with the combination of 5 days short length moving average and 60 days long length moving average, generate significantly higher profits compared to the buy-andhold strategy. Due to the supportive technical trading rules result, they also concluded that technical analysis can be used to yield profit even in the presence of transaction costs. Heng, 
Azizan and Yeap (2012) who applied 13 technical trading rules on 38 index-linked stocks covering a 7-year period from 1996 to 2009, also suggested that the Malaysian stock market in its weak form inefficiency during the period studied can still use some of the technical trading rules to generate return in the presence of transaction costs.

In the 1930s, the stock market trend discovered by Ralph Nelson Elliot were repetitive in form and reverse in a discernible pattern. The Elliot wave principle stated that there are two types of waves: impulsive and corrective. The impulsive waves are in the five-wave pattern, whereas the corrective waves are in the three-wave pattern (Frost \& Prechter, 2005, p.21). An earlier study by Chatterjee, O. Felix Ayadi and Maniam (2002) found that recognition of the historical pattern in the stock market can be effectively done based on the Elliot Wave Theory and Fibonacci numbers. Charussaengsuriya and Tharnpipat (2012) applied Elliot Wave Theory and Fibonacci numbers in their study of determining the optimal time to invest in the Thai bank securities portfolio. The analysis methodologies used by Charussaengsuriya and Tharnpipat (2012) will be replicated in this current study, in testing the predictive power of the technical trading rules in the context of Malaysian stock market

The literature on moving averages rules has shown mixed results of profitability and predictability. Hence it would be interesting to further investigate the Elliot Wave Theory and Fibonacci sequences. Moreever, studies related to the Elliot Wave and Fibonacci sequences are limited. Therefore, this study attempts to explore the incorporation of Fibonacci sequences into the Elliot wave theory to confirm the predictability of Moving Average Rules in the context of Malaysian stock market.

\section{METHODOLOGY}

This study analyses two of the technical trading rules, (i) Variable Moving Average and (ii) Elliot Wave Theory incorporated with Fibonacci numbers. Additionally, this study also attempts to examine the relationship between signals emitted by the Variable Moving Average rules and the daily returns of the stocks.

\subsection{Data Collection}

The secondary data of this study consist of the daily stock prices of the 30 largest capitalization companies listed in the main market of Bursa Malaysia. The sample period covers $3^{\text {rd }}$ January 2005 to $31^{\text {st }}$ December 2012. Companies with unavailable data within the sample period were eliminated. As a result, only 23 companies are left for the analysis of this study.

\subsection{Variable Moving Average Rules}

Variable Moving Average (VMA) rule is evaluated in this study due to the higher profitability and predictability, as evidenced by Brock et al. (1992). The short term moving averages used in this study are 1, 2 and 5 days, whereas the long term moving averages used in this study are 20, 50, $60,120,150,180$, and 200 days. This study also considered the percentage band of 1 percent in removing the "whiplashes" signals emitted. For the VMA rule, the buy (sell) signals are emitted when the short term moving average cross the long moving average upward (downward). However, with the inclusion of 1 percent percentage band, the buy (sell) signals are emitted when the short term moving average cross the long moving average upward (downward) for more than 1 percent. 
For instance, if the variable moving average rule is 2,20, the short term moving average is 2-day moving average and the long term moving average is 20-day moving average. Thus, the buy (sell) signals are emitted when the short term moving average cross the long moving average upward (downward). Investors are assumed to buy whenever the buy signal is emitted, and to continue holding as long as the short term moving average remain above the long term moving average. Investors are assumed to remain out of the market whenever the sell signal is emitted as long as the short term moving average remains below the long term moving average.

This study uses and tests the 42 VMA rules, as following: $(1,20),(1,20,0.01),(2,20)$, $(2,20,0.01),(5,20),(5,20,0.01),(1,50),(1,50,0.01),(2,50),(2,50,0.01),(5,50),(5,50,0.01),(1,60)$, $(1,60,0.01),(2,60),(2,60,0.01),(5,60),(5,60,0.01),(1,120),(1,120,0.01),(2,120),(2,120,0.01)$, $(5,120),(5,120,0.01),(1,150),(1,150,0.01),(2,150),(2,150,0.01),(5,150),(5,150,0.01),(1,180)$, $(1,180,0.01),(2,180),(2,180,0.01),(5,180),(5,180,0.01),(1,200), \quad(1,200,0.01), \quad(2,200)$, $(2,200,0.01),(5,200),(5,200,0.01)$.

First and foremost, all the daily returns within the sample period are computed in order to get the buy-and-hold strategy (unconditional) returns and separated into the daily returns for buy and sell signals. The daily returns are computed as log differences of particular individual stocks. That is

$$
R_{t}=\log \left(C_{t}\right)-\log \left(C_{t-1}\right)
$$

Where $R_{t}$ is the daily returns of the particular stock at time $t, C_{t}$ is the closing price of the particular stock at time $t, C_{t-1}$ is the closing price of the particular stock at time $t-1$. Based on the above formula, the mean and standard deviation for the unconditional return, buy return and sell return can be found. The number of buy and sell signals also can be calculated. In order to test the predictability and profitability of the variable moving average (VMA) rules, three hypotheses are developed and tested by using the t-test. The t-test used in this study also replicates the t-test used by Brock et al. (1992). According to Achuthan and Anubhai (2005), the VMA rules own predictive power when the difference between the average daily return generated by the buy signals and average daily return generated by the sell signals is greater than zero for any length of variable moving average rules.

The t-statistics for $\mathrm{H} 1$ [buy-sell $\left(\mathrm{R}_{\mathrm{B}}-\mathrm{R}_{\mathrm{S}}\right)$ ] are,

$$
\mathrm{H}_{1}: \mathrm{R}_{\mathrm{B}}-\mathrm{R}_{\mathrm{S}}>0
$$

$$
\left(\mu_{\mathrm{b}}-\mu_{\mathrm{s}}\right) /\left(\sigma^{2} / \mathrm{N}_{\mathrm{b}}+\sigma^{2} / \mathrm{N}_{\mathrm{s}}\right)^{1 / 2}
$$

Achuthan and Anubhai (2005) also mentioned that the buy (sell) signal will only benefit the investors when the return generated by buy (sell) signal is greater (lesser) than the unconditional returns.

$$
\begin{aligned}
& \mathrm{H}_{2}: \mathrm{R}_{\mathrm{B}}>\mathrm{R}_{\mathrm{U}} \\
& \mathrm{H}_{3}: \mathrm{R}_{\mathrm{S}}<\mathrm{R}_{\mathrm{U}}
\end{aligned}
$$

The t-statistics for $\mathrm{H} 2 \& \mathrm{H} 3$ [buy $\left(\mathrm{R}_{\mathrm{B}}\right)$ and sell $\left(\mathrm{R}_{\mathrm{S}}\right)$ ] are,

$$
\left(\mu_{\mathrm{r}}-\mu\right) /\left(\sigma^{2} / \mathrm{N}_{\mathrm{r}}+\sigma^{2} / \mathrm{N}\right)^{1 / 2}
$$

$\mathrm{R}_{\mathrm{B}}$ represented the return generated by the buy signal; $\mathrm{R}_{\mathrm{S}}$ represented return generated by the sell signal; $\mathrm{R}_{\mathrm{U}}$ represented the unconditional return (return generated by the buy-and-hold strategy). For t-statistics under $\mathrm{H} 1, \mu_{\mathrm{b}}$ and $\mu_{\mathrm{s}}$ are the mean return for the buy and sell signals; $\mathrm{N}_{\mathrm{b}}$ and $\mathrm{N}_{\mathrm{s}}$ are the number of buy and sell signals emitted. For t-statistics under $\mathrm{H} 2, \mu_{\mathrm{r}}$ are the mean return for either the buy or sell signals; $\mathrm{N}$ and $\mathrm{N}_{\mathrm{r}}$ are the number of observations and number of either buy and sell signals emitted respectively. 
The "double-or-out" framework applied by Brock et al. (1992), Bessembinder and Chan (1995), and Lai, Balachandler and Nor (2007) is applied again in this study in order to measure the profit generated from the application of the variable moving average rules. By using this framework, an investor is assumed to borrow at the risk free interest rate and doub] - ... the investment when the buy signal is generated; the investor will sell off the shares and inv (2) he risk free rate. The proxy of risk free rate used in this study is the same as that used by Lai et al. (2007), which is the average yield of the 3-months Malaysian Treasury Bills. This study also replicates the method applied by Lai et al. (2007) in measuring the profit of the variable moving average rules. The profits generated by the buy signals and the sell signals are calculated as follows:

Profit $($ Buy $)=[($ mean return $\mathrm{x}$ buy signals per year $)]-($ risk free interest rate $)$

Profit $($ Sell $)=($ risk free interest rate $)-[($ mean return $x$ buy signals per year $)]$

As applied by Lai et al. (2007), the profit before accounting for transactions costs is the combinations of profits from the buy and sell signals. The profit after accounting for transactions costs is calculated as follows:

Profit (After transaction costs) $=$ Profit (Before transaction costs) $-\mathrm{C} *\left(\mathrm{~N}_{\mathrm{b}}+\mathrm{N}_{\mathrm{s}}\right)$

Where $\mathrm{N}_{\mathrm{b}}$ and $\mathrm{N}_{\mathrm{s}}$ are the number of buy and sell signals respectively, $\mathrm{C}$ represents the $\operatorname{tr}$ : (4) on costs. The transaction costs used in this study is the same as Heng, Azizan and Yeap ( $\angle$ UI 2), where the transaction costs is $0.84 \%$ for retail trades and $0.44 \%$ for online trades.

\subsection{Elliot Wave Theory Incorporated With Fibonacci Numbers}

In order to recognize the pattern and wave by using Elliot Wave theory, there are a few principles that need to be followed. In the book of Frost and Prechter (2005), the Elliot Wave Principles are stated as below:

1. Wave 2 does not fall below the starting price of wave 1 .

2. Wave 3 is not the shortest wave by price movement when compared to wave 1 and wave 5 .

3. Wave 4 does not overlap the range of wave 1

Hence, these principles are used to identify the pattern wave in this study. The fundamental form of the Elliot Wave is shown in Figure 1:

\section{Figure 1: Fundamental Form of Elliot's Wave}

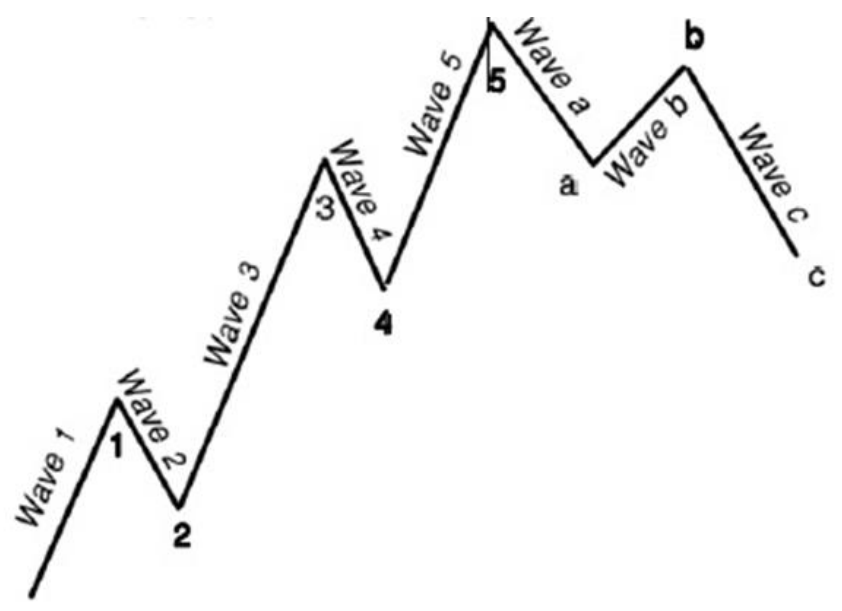


In the $13^{\text {th }}$ century, the sequence of the Fibonacci numbers was discovered by Leonardo Fibonacci. He then transferred the natural phenomena above into a series of number sequences $(0,1,1,2,3,5,8,13,21,34,55,89,144$ and so on until infinity). These numbers are correlated among each other as the number (starting from the third number in the sequence) is the summation of the two preceding numbers. For instances, 5 is the summation 2 and 3; 8 is the summation of 3 and 5; and 13 is the summation of 5 and 8 ).

Besides that, Fibonacci ratio of 0.618 and 1.618 were the special ratio found in the Fibonacci sequences. The ratio of any number to its subsequent number is approaches to the ratio 0.618.

$$
\mathrm{X}_{(\mathrm{n}-1)} / \mathrm{X}_{\mathrm{n}} \approx 0.618
$$

The ratio of any number to its preceding number is approaches to the ratio of 1.618. This ratio is also known as the golden ratio of Fibonacci sequences (Garg \& Garg, 2013).

$$
\mathrm{X}_{\mathrm{n}} / \mathrm{X}_{(\mathrm{n}-1)} \approx 1.618
$$

Where,

$\mathrm{X}=$ any number starting from the fifth numbers in the Fibonacci sequences, thus $\mathrm{n}$ must equal to 5 .

\subsubsection{Analysis Methodology}

This study incorporates the Fibonacci number into the Elliot Wave theory for the purpose of stock price prediction. The methodology used for the stock price prediction in this section is similar to the methodology applied by Charussaengsuriya and Tharnpipat (2012). The process of stock prices prediction based on Elliot wave and Fibonacci number has been divided into two steps for impulsive waves and corrective waves. For the impulsive waves, the steps for stock price prediction can be summarized as below:

1. Draw a candlestick chart for an eight-year term of stock prices and identify all the impulsive waves that occurred in each year.

2. Indicate the lowest point of the Impulse Waves.

3. The height of first wave is calculated by getting the difference between the highest point of the first wave with the lowest point of the first wave.

3. The height of the first wave is multiplied by Fibonacci ratio of 1.618, and then added with the highest point in Wave 1, to foresee the highest point in the impulsive waves.

For corrective waves, the steps for stock price prediction can be summarized as below:

4. Draw a candlestick chart for a three-year term of stock prices and identify all the Corrective waves that occurred in each year.

5. Indicate the lowest point of the Corrective Waves.

6. The height of first wave is calculated by getting the difference between the highest point of the first wave with the lowest point of the first wave.

7. The lowest point in Wave $\mathrm{A}$ is deducted with the product of the height of first wave and the Fibonacci ratio of 1.618. The resulting gain will be the predicted final prices of corrective waves.

\subsubsection{Accuracy Comparison}

In order to measure the accuracy of stock price prediction, this study replicates the method applied by Charussaengsuriya and Tharnpipat (2012). Thus, Geometric Mean of the error ratio of prediction is calculated as shown below.

$$
\text { Geometric Mean }=\sqrt[N]{\prod_{1}^{N}\left|\frac{P-\hat{P}}{P}\right|} \text { Where, }
$$

$\mathrm{N}=$ Number of waves found in the Impulsive Waves or Corrective Waves. 
$\mathrm{P}=$ The highest or lowest price for each of the impulsive wave or corrective wave, respectively. $\mathrm{P}^{\wedge}=$ Predicted prices for each of the impulsive wave or corrective wave

Next, the percentage of error that occurred between actual prices and predicted prices of the stock $\mathrm{x}$ can be calculated by multiplying the geometric means by the $100 \%$. The stock price prediction is considered accurate when the percentage of error is less than 10 percent. Thus two hypotheses are tested as below:

$\mathrm{H}_{4}$ : The percentage of error between the actual prices and predicted prices during the Impulsive Wave's cycle for stock $x$ is less than $10 \%$.

$\mathrm{H}_{5}$ : The percentage of error between the actual prices and predicted prices during the Corrective Wave's cycle for stock $\mathrm{x}$ is less than $10 \%$.

However, the percentage of error during the corrective waves has to be higher than the impulsive wave ones due to the higher risk and volatility of corrective waves.

\subsection{Regression Analysis}

Apart from testing the profitability and predictability of the technical trading rules intensively, this study aims to test the relationship between the stock price changes (daily returns) and signals emitted by variable moving average rules. For the past two decades, moving average rules had been widely examined, but only Bessembinder and Chan (1995) attempted in looking for the relationship between stock price changes (daily returns) and signals generated by trading rules.

The moving average rules emit buy (sell) signals when the short period moving average rises above (falls below) the long period moving average. By assuming that investors are following the buy signals given by the moving average rules at time $\mathrm{t}-1$, and executing the buy action at time $t$, the demand of the particular stock at time $t$ is going to exceed the supply, which will cause the price at time $t$ to increase. This is supported by one of the basic tenet of technical analysis, where the market action discounts everything. The interpretation for the tenet of market discounts everything is shown below:

"The technician (technical analysts) believes that the price could be affected by anything which include the fundamental, political and psychological factors. Otherwise, the factors were reflected in the price of the market. The technician claimed that the price action also reflected the shift in demand and supply, where the price rise (decline) when demand (supply) exceeds supply (demand)"

Based on the statement above, the hypotheses of the analysis are constructed as below:

$\mathrm{H}_{6}$ : There is a significant relationship between the signals emitted by variable moving average rules and stock price changes.

The regression model is shown as below:

Model 1 (Long-term moving average $=20$ days):

$$
\begin{aligned}
& \Delta S P_{t}=\beta_{0}+\beta_{1} V M A_{1,20,0, t-1}+\beta_{2} V M A_{1,20,0.01, t-1}+\beta_{3} V M A_{2,20,0, t-1}+\beta_{4} V M A_{2,20,0.01, t-1} \\
& +\beta_{5} V M A_{5,20,0, t-1}+\beta_{6} V M A_{5,20,0.01, t-1}
\end{aligned}
$$

Model 2 (Long-term moving average $=50$ days):

$$
\begin{aligned}
& \Delta S P_{t}=\beta_{0}+\beta_{1} V M A_{1,50,0, t-1}+\beta_{2} V M A_{1,50,0.01, t-1}+\beta_{3} V M A_{2,50,0, t-1}+\beta_{4} V M A_{2,50,0.01, t-1} \\
& +\beta_{5} V M A_{5,50,0, t-1}+\beta_{6} V M A_{5,50,0.01, t-1}
\end{aligned}
$$

Model 3 (Long-term moving average $=60$ days): 


$$
\begin{gathered}
\Delta S P_{t}=\beta_{0}+\beta_{1} V M A_{1,60,0, t-1}+\beta_{2} V M A_{1,60,0.01, t-1}+\beta_{3} V M A_{2,60,0, t-1}+\beta_{4} V M A_{2,60,0.01, t-1} \\
+\beta_{5} V M A_{5,60,0, t-1}+\beta_{6} V M A_{5,60,0.01, t-1}
\end{gathered}
$$

Model 4 (Long-term moving average $=120$ days):

$$
\begin{aligned}
& \Delta S P_{t}=\beta_{0}+\beta_{1} V M A_{1,120,0, t-1}+\beta_{2} V M A_{1,120,0.01, t-1}+\beta_{3} V M A_{2,120,0, t-1}+\beta_{4} V M A_{2,120,0.01, t-1} \\
& +\beta_{5} V M A_{5,120,0, t-1}+\beta_{6} V M A_{5,120,0.01, t-1}
\end{aligned}
$$

Model 5 (Long-term moving average $=150$ days):

$$
\begin{aligned}
& \Delta S P_{t}=\beta_{0}+\beta_{1} V M A_{1,150,0, t-1}+\beta_{2} V M A_{1,150,0.01, t-1}+\beta_{3} V M A_{2,150,0, t-1}+\beta_{4} V M A_{2,150,0.01, t-1} \\
& +\beta_{5} V M A_{5,150,0, t-1}+\beta_{6} V M A_{5,150,0.01, t-1}
\end{aligned}
$$

Model 6 (Long-term moving average $=180$ days):

$$
\begin{aligned}
& \Delta S P_{t}=\beta_{0}+\beta_{1} V M A_{1,180,0, t-1}+\beta_{2} V M A_{1,180,0.01, t-1}+\beta_{3} V M A_{2,180,0, t-1}+\beta_{4} V M A_{2,180,0.01, t-1} \\
& +\beta_{5} V M A_{5,180,0, t-1}+\beta_{6} V M A_{5,180,0.01, t-1}
\end{aligned}
$$

Model 7 (Long-term moving average $=200$ days):

$$
\begin{aligned}
& \Delta S P_{t}=\beta_{0}+\beta_{1} V M A_{1,200,0, t-1}+\beta_{2} V M A_{1,200,0.01, t-1}+\beta_{3} V M A_{2,200,0, t-1}+\beta_{4} V M A_{2,200,0.01, t-1} \\
& +\beta_{5} V M A_{5,200,0, t-1}+\beta_{6} V M A_{5,200,0.01, t-1}
\end{aligned}
$$

Where,

$\beta_{0}=$ Intercept of the regression model; $S P_{t}=$ Daily return on time $\mathrm{t}$

$V M A_{s, l, b, t-1}=$ Signals emitted by the particular variable moving average rule. Buy signal $=1$; Sell Signal $=-1$; Neutral Signal $=0$.The $(\mathrm{s})$ represents the short period moving average, (l) represents the long period moving average, (b) represents the trading band of a rules at time $t$.

This study applied the Ordinary Least Square (OLS) Regression Model to investigate the relationship between signals emitted by moving average rules and the stock price changes in the context of Malaysian stock market.

\section{RESULTS}

The summary statistics of the daily stock returns of 23 large capitalization companies' stocks are reported in Table 1.

Table 1

\section{Summary Statistics of the Large Capitalization Companies' Stocks}

\begin{tabular}{|l|c|}
\hline Mean & 0.01570 \\
\hline Standard Deviation & 0.83792 \\
\hline Sample Variance & 0.70210 \\
\hline Kurtosis & 684.86440 \\
\hline Skewness & -10.79932 \\
\hline Number of observations & 45448 \\
\hline
\end{tabular}

Table 1 reported that the daily returns across the large capitalization companies and studied period were 0.0157 percent, and the buy-and-hold strategy return (unconditional return) was 0.0157 percent. This indicated that an investor has the possibility to earn an average daily return of 0.0157 percent from the investment in the shares of large capitalization companies in the Malaysian stock market.

Table 2 reported the test results of 42 variable moving average (VMA) rules. Over the sample period of 2005 to 2012, all the VMA rules generated more buy signals than sell signals. The mean returns generated from buy signals are significantly higher than the unconditional return for only 10 VMA rules. Thus, the results provided a weak support against the $\mathrm{H}_{2}$. It is worth noting that the mean returns from the sell signals are significantly lesser than the unconditional 
return for all the VMA rules. Hence, hypothesis 3 is strongly supported. Besides that, the result of buy and sell return differential for all the VMA rules also show that it is significantly greater than zero. This provides a strong support to hypothesis 1 . Based on the result reported in Table 2, the VMA rules of $(2,60)$ since it produce highest pre- and after- transaction costs profit, as compared to the other VMA rules.

Table 3 reported the result of the regression analysis between the daily returns of the stocks and the signals emitted by the VMA rules. Among the 42 VMA rules tested in this study, the signals emitted by only 15 VMA rules show a significant relationship with the daily returns of the stock. However, only the signal from the VMA rules of $(2,20),(2,20,0.01),(5,50),(5,60)$, $(5,180,0.01),(5,200,0.01)$ show a significant positive relationship with stock prices. Hence, the results of the regression analysis only provided weak support to hypothesis 6 . 
Table 2

Test Result of Variable Length Moving Averages (VMA) Rules

\begin{tabular}{|c|c|c|c|c|c|c|c|c|c|}
\hline Test & N(Buy) & $\mathbf{N}$ (Sell) & Buy & Sell & Buy > 0 & Sell >0 & Buy-Sell & Profit & Profit (After) \\
\hline 1,20 & 25281 & 19730 & $\begin{array}{c}9.35189 \mathrm{E}-05 \\
(-2.3758)^{2}\end{array}$ & $\begin{array}{c}-0.03493 \\
(-7.0574)^{3 *}\end{array}$ & 0.3875 & 0.4251 & $\begin{array}{c}0.03502 \\
(4.3877)^{1 *}\end{array}$ & $\begin{array}{c}-0.01609^{\mathrm{B}} \\
-3.71660^{\mathrm{S}} \\
3.70051^{\mathrm{T}}\end{array}$ & $\begin{array}{l}2.62416^{\mathrm{TC} 1} \\
1.64566^{\mathrm{TC} 2}\end{array}$ \\
\hline $1,20,0.01$ & 17447 & 12644 & $\begin{array}{c}-5.32135 \mathrm{E}-03 \\
(-2.5802)\end{array}$ & $\begin{array}{c}-0.03121 \\
(-4.9902)^{*}\end{array}$ & 0.3911 & 0.4291 & $\begin{array}{c}0.02589 \\
(2.3264)^{*}\end{array}$ & $\begin{array}{c}-0.53351 \\
-2.11579 \\
1.58228 \\
\end{array}$ & $\begin{array}{l}0.86271 \\
0.20856\end{array}$ \\
\hline 2,20 & 25278 & 19733 & $\begin{array}{c}7.76511 \mathrm{E}-03 \\
(-1.2022)\end{array}$ & $\begin{array}{c}-0.02510 \\
(-5.7224)^{*}\end{array}$ & 0.3936 & 0.4173 & $\begin{array}{c}0.03286 \\
(4.1246)^{*}\end{array}$ & $\begin{array}{c}1.03783 \\
-2.66267 \\
3.70051\end{array}$ & $\begin{array}{l}2.62416 \\
1.64566\end{array}$ \\
\hline $2,20,0.01$ & 17023 & 12223 & $\begin{array}{l}4.20817 \mathrm{E}-03 \\
(-1.4290)\end{array}$ & $\begin{array}{c}-0.02327 \\
(-4.1740)^{*}\end{array}$ & 0.3983 & 0.4226 & $\begin{array}{c}0.02748 \\
(2.4989)^{*}\end{array}$ & $\begin{array}{c}0.36038 \\
-1.51704 \\
1.87743 \\
\end{array}$ & $\begin{array}{l}1.17807 \\
0.54228\end{array}$ \\
\hline 5,20 & 25262 & 19749 & $\begin{array}{c}0.01169 \\
(-0.6023)\end{array}$ & $\begin{array}{c}-0.00020 \\
(-5.0844)^{*}\end{array}$ & 0.4003 & 0.4087 & $\begin{array}{c}0.03175 \\
(4.0017)^{*}\end{array}$ & $\begin{array}{c}1.57557 \\
-2.12494 \\
3.70050\end{array}$ & $\begin{array}{l}2.62415 \\
1.64565\end{array}$ \\
\hline $5,20,0.01$ & 15777 & 11023 & $\begin{array}{c}3.42075 \mathrm{E}-03 \\
(-1.4221)\end{array}$ & $\begin{array}{c}-0.02238 \\
(-3.8226)^{*}\end{array}$ & 0.4037 & 0.4219 & $\begin{array}{c}0.02580 \\
(2.1586)^{*}\end{array}$ & $\begin{array}{c}0.26437 \\
-1.31192 \\
1.57629 \\
\end{array}$ & $\begin{array}{l}0.93542 \\
0.35281\end{array}$ \\
\hline 1,50 & 26199 & 18122 & $\begin{array}{l}0.01575 \\
(0.0076)\end{array}$ & $\begin{array}{c}-0.01698 \\
(-3.9619)^{*}\end{array}$ & 0.3978 & 0.4157 & $\begin{array}{c}0.03273 \\
(3.8241)^{*}\end{array}$ & $\begin{array}{c}2.21293 \\
-1.64382 \\
3.85674 \\
\end{array}$ & $\begin{array}{l}2.79689 \\
1.83339\end{array}$ \\
\hline $1,50,0.01$ & 20555 & 13190 & $\begin{array}{l}0.01639 \\
(0.1024)\end{array}$ & $\begin{array}{c}-0.02030 \\
(-4.0441)^{*}\end{array}$ & 0.4013 & 0.4206 & $\begin{array}{c}0.03669 \\
(3.7966)^{*}\end{array}$ & $\begin{array}{c}1.80162 \\
-1.42644 \\
3.22806 \\
\end{array}$ & $\begin{array}{l}2.42111 \\
1.68752\end{array}$ \\
\hline 2,50 & 26186 & 18135 & $\begin{array}{c}0.01434 \\
(-0.2035)\end{array}$ & $\begin{array}{c}-0.01901 \\
(-4.8658)^{*}\end{array}$ & 0.4013 & 0.4108 & $\begin{array}{c}0.03335 \\
(4.1592)^{*}\end{array}$ & $\begin{array}{c}2.01251 \\
-1.84424 \\
3.85675\end{array}$ & $\begin{array}{l}2.79690 \\
1.83340\end{array}$ \\
\hline $2,50,0.01$ & 21459 & 13615 & $\begin{array}{c}0.018228 \\
(0.3757)\end{array}$ & $\begin{array}{c}-0.01656 \\
(-3.8155)^{*}\end{array}$ & 0.4056 & 0.4144 & $\begin{array}{c}0.03476 \\
(3.7534)^{*}\end{array}$ & $\begin{array}{c}2.09690 \\
-1.19469 \\
3.29159\end{array}$ & $\begin{array}{l}2.45287 \\
1.69039\end{array}$ \\
\hline
\end{tabular}


Table 2

Test Result of Variable Length Moving Averages (VMA) Rules (Cont.')

\begin{tabular}{|c|c|c|c|c|c|c|c|c|c|}
\hline Test & N(Buy) & $\mathbf{N}($ Sell) & Buy & Sell & Buy $>0$ & Sell $>0$ & Buy-Sell & Profit & Profit (After) \\
\hline 5,50 & 26165 & 18156 & $\begin{array}{l}0.02062 \\
(0.7383)\end{array}$ & $\begin{array}{c}-9.9529 \mathrm{E}-03 \\
(-3.6072)^{*}\end{array}$ & 0.4077 & 0.4015 & $\begin{array}{c}0.03058 \\
(3.8176)^{*}\end{array}$ & $\begin{array}{c}2.90359 \\
-0.95315 \\
3.85674\end{array}$ & $\begin{array}{l}2.79689 \\
1.83339\end{array}$ \\
\hline $5,50,0.01$ & 21149 & 13366 & $\begin{array}{l}0.02051 \\
(0.7107)\end{array}$ & $\begin{array}{c}-9.66317 \mathrm{E}-03 \\
(-2.9919)^{*}\end{array}$ & 0.4085 & 0.4094 & $\begin{array}{c}0.03018 \\
(3.2379)^{*}\end{array}$ & $\begin{array}{c}2.32894 \\
-0.67301 \\
3.00195\end{array}$ & $\begin{array}{l}2.17659 \\
1.42626\end{array}$ \\
\hline 1,60 & 26374 & 17717 & $\begin{array}{l}0.01786 \\
(0.3599)\end{array}$ & $\begin{array}{c}-0.01548 \\
(-3.7249)^{*}\end{array}$ & 0.3998 & 0.4149 & $\begin{array}{c}0.03334 \\
(3.8473)^{*}\end{array}$ & $\begin{array}{c}2.53054 \\
-1.46188 \\
3.99242\end{array}$ & $\begin{array}{l}2.93807 \\
1.97957\end{array}$ \\
\hline $1,60,0.01$ & 22322 & 13674 & $\begin{array}{l}0.01926 \\
(0.5499)\end{array}$ & $\begin{array}{c}-0.02013 \\
(-4.2545)^{*}\end{array}$ & 0.4042 & 0.4188 & $\begin{array}{c}0.03939 \\
(4.3515)^{*}\end{array}$ & $\begin{array}{c}2.30758 \\
-1.46720 \\
3.77478\end{array}$ & $\begin{array}{l}2.91400 \\
2.13148\end{array}$ \\
\hline 2,60 & 26363 & 17728 & $\begin{array}{c}0.03641 \\
(3.3927)^{*}\end{array}$ & $\begin{array}{c}-0.01036 \\
(-3.1822)^{*}\end{array}$ & 0.4039 & 0.4087 & $\begin{array}{c}0.04677 \\
(5.4581)^{*}\end{array}$ & $\begin{array}{c}5.18767 \\
-0.96919 \\
6.15686\end{array}$ & $\begin{array}{l}5.10251 \\
4.14401\end{array}$ \\
\hline $2,60,0.01$ & 22293 & 13641 & $\begin{array}{l}0.02105 \\
(0.8078)\end{array}$ & $\begin{array}{c}-0.01612 \\
(-3.7702)^{*}\end{array}$ & 0.4073 & 0.4151 & $\begin{array}{c}0.03716 \\
(4.0518)^{*}\end{array}$ & $\begin{array}{c}2.52088 \\
-1.16600 \\
3.68689\end{array}$ & $\begin{array}{l}2.82759 \\
2.04642\end{array}$ \\
\hline 5,60 & 26331 & 17760 & $\begin{array}{c}0.02502 \\
(1.5231)^{*}\end{array}$ & $\begin{array}{c}-4.87487 \mathrm{E}-03 \\
(-2.5200)^{*}\end{array}$ & 0.4069 & 0.4042 & $\begin{array}{c}0.02989 \\
(3.4944)^{*}\end{array}$ & $\begin{array}{c}3.55083 \\
-0.44159 \\
3.99242\end{array}$ & $\begin{array}{l}2.93807 \\
1.97957\end{array}$ \\
\hline $5,60,0.01$ & 22068 & 13487 & $\begin{array}{l}0.02406 \\
(1.2588)\end{array}$ & $\begin{array}{c}-0.01183 \\
(-3.2525)^{*}\end{array}$ & 0.4110 & 0.4114 & $\begin{array}{c}0.03589 \\
(3.8957)^{*}\end{array}$ & $\begin{array}{c}2.85699 \\
-0.83833 \\
3.69532\end{array}$ & $\begin{array}{l}2.84509 \\
2.07215\end{array}$ \\
\hline 1,120 & 27088 & 15623 & $\begin{array}{l}0.02174 \\
(1.0184)\end{array}$ & $\begin{array}{c}-0.01132 \\
(-3.0332)^{*}\end{array}$ & 0.4070 & 0.4073 & $\begin{array}{c}0.03306 \\
(3.6155)^{*}\end{array}$ & $\begin{array}{c}3.17096 \\
-0.93263 \\
4.10359\end{array}$ & $\begin{array}{l}3.08224 \\
2.15374\end{array}$ \\
\hline $1,120,0.01$ & 24461 & 13246 & $\begin{array}{l}0.02348 \\
(1.2554)\end{array}$ & $\begin{array}{c}-8.91083 \mathrm{E}-03 \\
(-2.4569)^{*}\end{array}$ & 0.4102 & 0.4083 & $\begin{array}{c}0.03239 \\
(3.1189)^{*}\end{array}$ & $\begin{array}{c}3.09268 \\
-0.61254 \\
3.70523\end{array}$ & $\begin{array}{l}2.80354 \\
1.98382\end{array}$ \\
\hline
\end{tabular}


Table 2

Test Result of Variable Length Moving Averages (VMA) Rules (Cont.')

\begin{tabular}{|c|c|c|c|c|c|c|c|c|c|}
\hline Test & N(Buy) & $\mathbf{N}($ Sell) & Buy & Sell & Buy $>0$ & Sell >0 & Buy-Sell & Profit & Profit (After) \\
\hline 2,120 & 27098 & 15613 & $\begin{array}{c}0.02467 \\
(1.5175)^{*}\end{array}$ & $\begin{array}{c}-6.17885 \mathrm{E}-03 \\
(-2.4562)^{*}\end{array}$ & 0.4087 & 0.4043 & $\begin{array}{c}0.03088 \\
(3.3768)^{*}\end{array}$ & $\begin{array}{c}3.60823 \\
-0.49536 \\
4.10359 \\
\end{array}$ & $\begin{array}{l}3.08224 \\
2.15374\end{array}$ \\
\hline $2,120,0.01$ & 24411 & 13206 & $\begin{array}{c}0.02546 \\
(1.5269)^{*}\end{array}$ & $\begin{array}{c}-0.01124 \\
(-3.0151)^{*}\end{array}$ & 0.4119 & 0.4050 & $\begin{array}{c}0.03670 \\
(3.8728)^{*}\end{array}$ & $\begin{array}{c}3.34876 \\
-0.77805 \\
4.12681\end{array}$ & $\begin{array}{l}3.22727 \\
2.40951\end{array}$ \\
\hline 5,120 & 27113 & 15598 & $\begin{array}{c}0.02607 \\
(1.7509)^{*}\end{array}$ & $\begin{array}{c}-3.77291 \mathrm{E}-03 \\
(-2.1826)^{*}\end{array}$ & 0.4107 & 0.4010 & $\begin{array}{c}0.02984 \\
(3.2603)^{*}\end{array}$ & $\begin{array}{c}3.81269 \\
-0.29090 \\
4.10359\end{array}$ & $\begin{array}{l}3.08224 \\
2.15374\end{array}$ \\
\hline $5,120,0.01$ & 24302 & 13169 & $\begin{array}{c}0.02832 \\
(2.0288)^{*}\end{array}$ & $\begin{array}{c}-9.01584 \mathrm{E}-03 \\
(-2.8810)^{*}\end{array}$ & 0.4147 & 0.4035 & $\begin{array}{c}0.03733 \\
(4.1385)^{*}\end{array}$ & $\begin{array}{c}3.71090 \\
-0.61633 \\
4.32723\end{array}$ & $\begin{array}{l}3.43118 \\
2.61660\end{array}$ \\
\hline 1,150 & 27179 & 14842 & $\begin{array}{l}0.01754 \\
(0.2856)\end{array}$ & $\begin{array}{c}-0.01440 \\
(-3.7778)^{*}\end{array}$ & 0.4095 & 0.4028 & $\begin{array}{c}0.03194 \\
(3.7103)^{*}\end{array}$ & $\begin{array}{c}2.56187 \\
-1.13240 \\
3.69427\end{array}$ & $\begin{array}{l}2.68942 \\
1.77592\end{array}$ \\
\hline $1,150,0.01$ & 24958 & 12904 & $\begin{array}{l}0.02329 \\
(1.2364)\end{array}$ & $\begin{array}{c}-9.38618 \mathrm{E}-03 \\
(-2.8831)^{*}\end{array}$ & 0.4127 & 0.4015 & $\begin{array}{c}0.03268 \\
(3.5971)^{*}\end{array}$ & $\begin{array}{c}3.13072 \\
-0.62932 \\
3.76003\end{array}$ & $\begin{array}{l}2.85464 \\
2.03155\end{array}$ \\
\hline 2,150 & 27227 & 14794 & $\begin{array}{l}0.02084 \\
(0.7984)\end{array}$ & $\begin{array}{c}-8.31107 \mathrm{E}-03 \\
(-3.0099)^{*}\end{array}$ & 0.4115 & 0.3991 & $\begin{array}{c}0.02915 \\
(3.3841)^{*}\end{array}$ & $\begin{array}{r}3.05498 \\
-0.63929 \\
3.69426\end{array}$ & $\begin{array}{l}2.68941 \\
1.77591\end{array}$ \\
\hline $2,150,0.01$ & 24979 & 12847 & $\begin{array}{l}0.02320 \\
(1.1794)\end{array}$ & $\begin{array}{c}-6.20202 \mathrm{E}-03 \\
(-2.4115)^{*}\end{array}$ & 0.4153 & 0.3981 & $\begin{array}{c}0.02940 \\
(3.0647)^{*}\end{array}$ & $\begin{array}{r}3.12076 \\
-0.40409 \\
3.52485\end{array}$ & $\begin{array}{l}2.62032 \\
1.79801\end{array}$ \\
\hline 5,150 & 27178 & 14843 & $\begin{array}{l}0.02269 \\
(1.0839)\end{array}$ & $\begin{array}{c}-4.97532 \mathrm{E}-03 \\
(-2.5969)^{*}\end{array}$ & 0.4124 & 0.3976 & $\begin{array}{c}0.02766 \\
(3.2149)^{*}\end{array}$ & $\begin{array}{c}3.32186 \\
-0.37241 \\
3.69427\end{array}$ & $\begin{array}{l}2.68942 \\
1.77592\end{array}$ \\
\hline $5,150,0.01$ & 24890 & 12815 & $\begin{array}{l}0.02416 \\
(1.2525)\end{array}$ & $\begin{array}{c}-2.55438 \mathrm{E}-03 \\
(-2.0912)^{*}\end{array}$ & 0.4160 & 0.3968 & $\begin{array}{c}0.02671 \\
(2.8018)^{*}\end{array}$ & $\begin{array}{c}3.23883 \\
-0.14896 \\
3.38780\end{array}$ & $\begin{array}{l}2.48616 \\
1.66648\end{array}$ \\
\hline
\end{tabular}


Table 2

Test Result of Variable Length Moving Averages (VMA) Rules (Cont.')

\begin{tabular}{|c|c|c|c|c|c|c|c|c|c|}
\hline Test & N(Buy) & $\mathbf{N}($ Sell $)$ & Buy & Sell & Buy $>0$ & Sell >0 & Buy-Sell & Profit & Profit (After) \\
\hline 1,180 & 27166 & 14165 & $\begin{array}{l}0.02063 \\
(0.7666)\end{array}$ & $\begin{array}{c}-0.01025 \\
(-3.1559)^{*}\end{array}$ & 0.4131 & 0.4004 & $\begin{array}{c}0.03089 \\
(3.4936)^{*}\end{array}$ & $\begin{array}{c}3.01756 \\
-0.76052 \\
3.77808\end{array}$ & $\begin{array}{l}2.78973 \\
1.89123\end{array}$ \\
\hline $1,180,0.01$ & 24597 & 12089 & $\begin{array}{l}0.02116 \\
(0.8079)\end{array}$ & $\begin{array}{c}-9.52236 \mathrm{E}-03 \\
(-2.7958)^{*}\end{array}$ & 0.4155 & 0.3980 & $\begin{array}{c}0.03068 \\
(3.1284)^{*}\end{array}$ & $\begin{array}{c}2.80000 \\
-0.59669 \\
3.39670\end{array}$ & $\begin{array}{l}2.51942 \\
1.72190\end{array}$ \\
\hline 2,180 & 27177 & 14154 & $\begin{array}{l}0.02263 \\
(1.1125)\end{array}$ & $\begin{array}{c}-6.42029 \mathrm{E}-03 \\
(-2.4932)^{*}\end{array}$ & 0.4148 & 0.3972 & $\begin{array}{c}0.02905 \\
(3.1215)^{*}\end{array}$ & $\begin{array}{c}3.31315 \\
-0.46493 \\
3.77809\end{array}$ & $\begin{array}{l}2.78974 \\
1.89124\end{array}$ \\
\hline $2,180,0.01$ & 25315 & 12507 & $\begin{array}{l}0.02413 \\
(1.2613)\end{array}$ & $\begin{array}{c}-4.45172 \mathrm{E}-03 \\
(-2.2668)^{*}\end{array}$ & 0.4169 & 0.3963 & $\begin{array}{c}0.02858 \\
(2.9673)^{*}\end{array}$ & $\begin{array}{c}3.29021 \\
-0.27366 \\
3.56387\end{array}$ & $\begin{array}{l}2.65943 \\
1.83721\end{array}$ \\
\hline 5,180 & 27140 & 14191 & $\begin{array}{c}0.02381 \\
(1.3010)^{*}\end{array}$ & $\begin{array}{c}-4.20607 \mathrm{E}-03 \\
(-2.2662)^{*}\end{array}$ & 0.4157 & 0.3955 & $\begin{array}{c}0.02801 \\
(3.0369)^{*}\end{array}$ & $\begin{array}{c}3.48264 \\
-0.29545 \\
3.77809\end{array}$ & $\begin{array}{l}2.78974 \\
1.89124\end{array}$ \\
\hline $5,180,0.01$ & 24540 & 12537 & $\begin{array}{c}0.02682 \\
(1.7376)^{*}\end{array}$ & $\begin{array}{l}-2.30 \mathrm{E}-04 \\
(-1.7259)^{*}\end{array}$ & 0.4167 & 0.3940 & $\begin{array}{c}0.02705 \\
(2.7717)^{*}\end{array}$ & $\begin{array}{l}3.54861 \\
0.01327 \\
3.53534\end{array}$ & $\begin{array}{l}2.64871 \\
1.84269\end{array}$ \\
\hline 1,200 & 27104 & 13767 & $\begin{array}{l}0.02098 \\
(0.8192)\end{array}$ & $\begin{array}{c}-0.01061 \\
(-3.1388)^{*}\end{array}$ & 0.4148 & 0.4002 & $\begin{array}{c}0.03159 \\
(3.5124)^{*}\end{array}$ & $\begin{array}{c}3.06106 \\
-0.76516 \\
3.82621\end{array}$ & $\begin{array}{l}2.84886 \\
1.96036\end{array}$ \\
\hline $1,200,0.01$ & 25693 & 12177 & $\begin{array}{l}0.02116 \\
(0.8218)\end{array}$ & $\begin{array}{c}-9.84692 \mathrm{E}-03 \\
(-2.8214)^{*}\end{array}$ & 0.4080 & 0.4008 & $\begin{array}{c}0.03101 \\
(3.1767)^{*}\end{array}$ & $\begin{array}{c}2.92612 \\
-0.62272 \\
3.54884\end{array}$ & $\begin{array}{l}2.64325 \\
1.81999\end{array}$ \\
\hline 2,200 & 27110 & 13761 & $\begin{array}{l}0.02303 \\
(1.1379)\end{array}$ & $\begin{array}{c}-6.55938 \mathrm{E}-03 \\
(-2.6569)^{*}\end{array}$ & 0.4165 & 0.3967 & $\begin{array}{c}0.02959 \\
(3.2916)^{*}\end{array}$ & $\begin{array}{c}3.36458 \\
-0.46162 \\
3.82621\end{array}$ & $\begin{array}{l}2.84886 \\
1.96036\end{array}$ \\
\hline $2,200,0.01$ & 25563 & 12377 & $\begin{array}{l}0.02399 \\
(1.2480)\end{array}$ & $\begin{array}{c}-5.1213 \mathrm{E}-03 \\
(-2.3228)^{*}\end{array}$ & 0.4180 & 0.3961 & $\begin{array}{l}0.02911 \\
(3.009)^{*}\end{array}$ & $\begin{array}{c}3.30367 \\
-0.31555 \\
3.61922\end{array}$ & $\begin{array}{l}2.71196 \\
1.88718\end{array}$ \\
\hline
\end{tabular}


Table 2

Test Result of Variable Length Moving Averages (VMA) Rules (Cont.')

\begin{tabular}{|c|c|c|c|c|c|c|c|c|c|}
\hline Test & N(Buy) & N(Sell) & Buy & Sell & Buy $>0$ & Sell > 0 & Buy-Sell & Profit & Profit (After) \\
\hline 5,200 & 27066 & 13805 & $\begin{array}{c}0.02492 \\
(1.4287)^{*}\end{array}$ & $\begin{array}{c}-2.91571 \mathrm{E}-03 \\
(-2.2288)^{*}\end{array}$ & 0.4175 & 0.3949 & $\begin{array}{c}0.02783 \\
(3.1023)^{*}\end{array}$ & $\begin{array}{c}3.63638 \\
-0.18982 \\
3.82620\end{array}$ & $\begin{array}{l}2.84885 \\
1.96035\end{array}$ \\
\hline $5,200,0.01$ & 25506 & 12373 & $\begin{array}{c}0.02606 \\
(1.5566)^{*}\end{array}$ & $\begin{array}{l}-8.68 \mathrm{E}-05 \\
(-1.7627)^{*}\end{array}$ & 0.4193 & 0.3924 & $\begin{array}{c}0.02615 \\
(2.7024)^{*}\end{array}$ & $\begin{array}{c}3.58340 \\
0.023103 \\
3.56030\end{array}$ & $\begin{array}{l}2.65450 \\
1.83104\end{array}$ \\
\hline
\end{tabular}

*Significant at 5\% level of significance, ** Significant at 5\% level of significance

Notes:

1 The t-statistics used to test hypothesis 1 that the difference between buy and sell returns is greater than zero.

2 The t-statistics used to test hypothesis 2 that the buy return is higher than the unconditional return.

The t-statistics used to test hypothesis 3 that less return is lesser than the unconditional return.

${ }^{\text {B }}$ Profit for buy signals, ${ }^{\mathrm{S}}$ Profit for sell signals, ${ }^{\mathrm{T}} \quad$ Total profit for buy and sell signals, ${ }^{\mathrm{TC}}$ \& ${ }^{\mathrm{TC}} 2$ Profit after transaction costs of $0.44 \%$ and $0.84 \%$.

$\mathrm{N}$ (Buy) refers to the number of buy signals emitted, $\mathrm{N}($ Sell) refers to the number of sell signals emitted.

Buy $>0$ is the fraction when the return of the buy signal are more than zero, Sell $>0$ is the fraction when the return of the sell signal are more than zero. 
Table 3

Results of Regression Analysis (Dependent Variable: Daily Returns of the stocks)

Table 3a

Model 1: LMA = 20 days

\begin{tabular}{|l|l|l|l|}
\hline Variables & Coefficient & t-statistics & $p$-value \\
\hline Intercept & 0.00017 & 4.26625 & 0.00002 \\
\hline 1,20 & -0.00035 & -3.94845 & $\mathbf{0 . 0 0 0 0 8}$ \\
\hline $1,20,0.01$ & -0.00049 & -3.70595 & $\mathbf{0 . 0 0 0 2 1}$ \\
\hline 2,20 & 0.00020 & 2.16855 & $\mathbf{0 . 0 3 0 1 2}$ \\
\hline $2,20,0.01$ & 0.00047 & 3.21467 & $\mathbf{0 . 0 0 1 3 1}$ \\
\hline 5,20 & 0.00009 & 1.35251 & 0.17622 \\
\hline $5,20,0.01$ & -0.00008 & -0.79007 & 0.42949 \\
\hline
\end{tabular}

Table 3b

Model 2: $\mathrm{LMA}=\mathbf{5 0}$ days

\begin{tabular}{|l|l|l|l|}
\hline Variables & Coefficient & t-statistics & $p$-value \\
\hline Intercept & 0.00016 & 3.84212 & 0.00012 \\
\hline 1,50 & 0.00009 & 0.78946 & 0.42984 \\
\hline $1,50,0.01$ & -0.00018 & -1.36722 & 0.17156 \\
\hline 2,50 & -0.00034 & -2.74807 & $\mathbf{0 . 0 0 6 0 0}$ \\
\hline $2,50,0.01$ & 0.00000 & -0.01146 & 0.99086 \\
\hline 5,50 & 0.00023 & 2.35600 & $\mathbf{0 . 0 1 8 4 8}$ \\
\hline $5,50,0.01$ & 0.00023 & 1.70714 & 0.08780 \\
\hline
\end{tabular}

Table 3c

Model 3: $\mathrm{LMA}$ = 60 days

\begin{tabular}{|l|l|l|l|}
\hline Variables & Coefficient & t-statistics & $p$-value \\
\hline Intercept & 0.00016 & 3.97836 & 0.00007 \\
\hline 1,60 & -0.00018 & -1.53931 & 0.12373 \\
\hline $1,60,0.01$ & -0.00034 & -1.96254 & $\mathbf{0 . 0 4 9 7 1}$ \\
\hline 2,60 & 0.00015 & 1.17488 & 0.24005 \\
\hline $2,60,0.01$ & 0.00000 & 0.01082 & 0.99137 \\
\hline 5,60 & 0.00030 & 2.85879 & $\mathbf{0 . 0 0 4 2 5}$ \\
\hline $5,60,0.01$ & 0.00010 & 0.68164 & 0.49547 \\
\hline
\end{tabular}

Table 3d

Model 4: LMA = 120 days

\begin{tabular}{|l|l|l|l|}
\hline Independent Variables & Coefficient & t-statistics & $p$-value \\
\hline Intercept & 0.00016 & 3.66277 & 0.00025 \\
\hline 1,120 & -0.00039 & -2.53334 & $\mathbf{0 . 0 1 1 3 0}$ \\
\hline $1,120,0.01$ & 0.00002 & 0.10709 & 0.91472 \\
\hline 2,120 & 0.00031 & 1.86969 & 0.06153 \\
\hline $2,120,0.01$ & -0.00025 & -1.03817 & 0.29920 \\
\hline 5,120 & 0.00019 & 1.43327 & 0.15179 \\
\hline $5,120,0.01$ & 0.00021 & 1.18458 & 0.23619 \\
\hline
\end{tabular}


Table 3e

Model 5: LMA = 150 days

\begin{tabular}{|l|l|l|l|}
\hline Independent Variables & Coefficient & t-statistics & $p$-value \\
\hline Intercept & 0.00014 & 3.19613 & 0.00139 \\
\hline 1,150 & -0.00072 & -4.33383 & $\mathbf{0 . 0 0 0 0 1}$ \\
\hline $1,150,0.01$ & 0.00015 & 0.67470 & 0.49987 \\
\hline 2,150 & 0.00020 & 1.15684 & 0.24734 \\
\hline $2,150,0.01$ & 0.00007 & 0.26656 & 0.78981 \\
\hline 5,150 & 0.00010 & 0.70902 & 0.47832 \\
\hline $5,150,0.01$ & 0.00029 & 1.55635 & 0.11963 \\
\hline
\end{tabular}

Table 3f

Model 6: $\mathrm{LMA}=180$ days

\begin{tabular}{|l|l|l|l|}
\hline Independent Variables & Coefficient & t-statistics & $p$-value \\
\hline Intercept & 0.00015 & 3.36324 & 0.00077 \\
\hline 1,180 & -0.00041 & -2.19837 & $\mathbf{0 . 0 2 7 9 3}$ \\
\hline $1,180,0.01$ & -0.00042 & -2.39374 & $\mathbf{0 . 0 1 6 6 8}$ \\
\hline 2,180 & 0.00017 & 0.85530 & 0.39239 \\
\hline $2,180,0.01$ & 0.00029 & 1.22539 & 0.22043 \\
\hline 5,180 & -0.00005 & -0.29570 & 0.76746 \\
\hline $5,180,0.01$ & 0.00050 & 2.87407 & $\mathbf{0 . 0 0 4 0 5}$ \\
\hline
\end{tabular}

Table 3g

Model 7: LMA = 200 days

\begin{tabular}{|l|l|l|l|}
\hline Independent Variables & Coefficient & t-statistics & $p$-value \\
\hline Intercept & 0.00014 & 3.20480 & 0.00135 \\
\hline 1,200 & -0.00038 & -1.95666 & 0.05039 \\
\hline $1,200,0.01$ & -0.00053 & -2.63029 & $\mathbf{0 . 0 0 8 5 3}$ \\
\hline 2,200 & 0.00012 & 0.56068 & 0.57502 \\
\hline $2,200,0.01$ & 0.00020 & 0.74365 & 0.45709 \\
\hline 5,200 & 0.00006 & 0.32189 & 0.74754 \\
\hline $5,200,0.01$ & 0.00063 & 2.81616 & $\mathbf{0 . 0 0 4 8 6}$ \\
\hline
\end{tabular}

Table 4 reported the test result of another indicator (Elliot wave incorporated with Fibonacci numbers) that was tested in this study. The result revealed that the occurrences of fundamental 5 wave pattern of impulsive were not frequent as the average number of 5 wave pattern occurrences was almost half of the average number of 3 wave pattern occurrences. On the other hand, the corrective waves were not found from the companies analysed within the studied period. The results also indicated that the average percentage error of impulsive is less than the percentage error of corrective waves. At the level of significance of 5 percent, the average percentage error of impulsive waves is significantly less than the level of 10 percent. This is consistent with the findings of Charussaengsuriya and Tharnpipat (2012). Thus, this provides a strong support to hypothesis 4 . On the other hand, the average percentage error of corrective waves shows an insignificant result and hypothesis 5 is not supported. 
Table 4

Test Result of Elliot Wave Theory Incorporated with Fibonacci numbers

\begin{tabular}{|c|c|c|c|c|c|}
\hline \multirow[t]{2}{*}{ Stock } & \multicolumn{2}{|c|}{ Impulsive Waves } & \multirow{2}{*}{$\begin{array}{l}\text { Corrective } \\
\text { Waves } \\
\text { (Number of } \\
\text { Waves) }\end{array}$} & \multirow{2}{*}{$\begin{array}{l}\text { Average Error } \\
\text { (Geomean) - } \\
\text { Impulsive Wave }\end{array}$} & \multirow{2}{*}{$\begin{array}{l}\text { Average } \\
\text { Error } \\
\text { (Geomean) } \\
\text {-Corrective } \\
\text { Waves }\end{array}$} \\
\hline & $\begin{array}{c}\text { Number of } 3 \text { Waves } \\
\text { Pattern Occurred }\end{array}$ & $\begin{array}{l}\text { Number of } 5 \text { waves } \\
\text { pattern Occurred }\end{array}$ & & & \\
\hline 1 & 2 & 7 & 8 & 8.6621 & 15.5121 \\
\hline 2 & 8 & 4 & 8 & 11.9935 & 14.7831 \\
\hline 3 & 9 & 4 & 4 & 6.8286 & 3.9549 \\
\hline 4 & 6 & 2 & 4 & 4.2715 & 11.7605 \\
\hline 5 & 4 & 4 & 5 & 7.9961 & 4.8752 \\
\hline 6 & 3 & 5 & 3 & 8.1551 & 2.5569 \\
\hline 7 & 4 & 6 & 3 & 3.3719 & 2.6355 \\
\hline 8 & 6 & 3 & 3 & 7.0867 & 5.7402 \\
\hline 9 & 9 & 2 & 2 & 4.0038 & 10.4656 \\
\hline 10 & 4 & 5 & 2 & 7.5877 & 31.5003 \\
\hline 11 & 4 & 4 & 0 & 6.0668 & - \\
\hline 12 & 5 & 4 & 4 & 6.6982 & 8.7539 \\
\hline 13 & 6 & 4 & 2 & 11.9049 & 20.6789 \\
\hline 14 & 2 & 6 & 1 & 2.0237 & 8.8667 \\
\hline 15 & 5 & 3 & 1 & 10.1596 & 12.4062 \\
\hline 16 & 10 & 2 & 2 & 5.3871 & 16.9530 \\
\hline 17 & 6 & 4 & 2 & 5.0129 & 9.5031 \\
\hline 18 & 7 & 3 & 4 & 7.0830 & 18.3798 \\
\hline 19 & 10 & 2 & 5 & 6.4450 & 4.8122 \\
\hline 20 & 6 & 2 & 0 & 11.9386 & - \\
\hline 21 & 10 & 0 & 6 & 5.3960 & 9.2695 \\
\hline 22 & 7 & 3 & 1 & 11.1997 & 13.8299 \\
\hline 23 & 6 & 4 & 2 & 8.2963 & 11.8065 \\
\hline Average & 6.04 & 3.61 & 3.13 & 7.2856 & 11.3830 \\
\hline & & & t-statistics & -4.66893 & 0.91665 \\
\hline
\end{tabular}

\section{CONCLUSIONS}

Technical analysis is one of the tools usually used by investors in analysing the stock market trend and finding the optimal time to do their equity investment. In this context, the findings of this study indicate that there is a potential for technical analysis to generate higher return above the buy-and-hold strategy. The results of testing 42 VMA rules showed that there is a possibility to generate return even when transaction costs are taken into account. In addition, the indicator of Elliot Wave incorporated with Fibonacci numbers was found to be useful in predicting the trend of the stock market, as the percentage error of the impulsive wave prediction is significantly less than 10 percent.

\section{Acknowledgement}

Financial support from University Malaysia Sarawak and Fundamental Research Grant Scheme [FRGS/ SS05 (04)/ 1149/2014(16)] are gratefully acknowledged. All remaining flaws are the responsibilities of the author. 


\section{References}

Abbad, J., Fardousi, B., \& Abbad, M. (2014). Advantages of using technical analysis to predict future prices on the Amman stock exchange. International Journal of Business and Management, 9(2), 1-16.

Achuthan, S., \& Anubhai, R. (2005). Effectiveness of variable length moving average ( VMA ) trading rules in the Indian stock market. Finance India, (4), 1375-1391.

Ahmed, P., Beck, K., \& Goldreyer, E. (2000). Can moving average technical trading strategies help in volatile and declining markets? A study of some emerging Asian markets. Managerial Finance, 26(6), 49-62.

Alexander, S. S. (1961). Price movements in speculative markets: trends or random walks. Industrial Management Review, 2, 7-26.

Bessembinder, H., \& Chan, K. (1995). The profitability of technical trading rules in the Asian stock markets. Pacific-Basin Finance Journal, 3, 257-284.

Bessembinder, H., \& Chan, K. (1998). Market efficiency and the returns to technical analysis. Financial Management, 27(2), 5-17.

Brock, W., Lakonishok, J., \& LeBaron, B. (1992). Simple technical trading rules and the stochastic properties of stock returns. Journal of Finance, 47(5), 1731-1764.

Campbell, H. M. (2011). Simple technical trading rules on the JSE Securities Exchange of South Africa , Part 2. In Proceedings of the World Congress on Engineering (Vol. 1). London.

Charussaengsuriya, R., \& Tharnpipat, T. (2012). Technical analysis of stock prices using Elliot wave theory and Fibonacci number. The Empirical Econometrics and Quantitative Economics Letters, 1(1), 91-102.

Chatterjee, A., O. Felix Ayadi, S., \& Maniam, B. (2002). The applications of Fibonacci sequence and Elliot Wave Theory in predicting the security price movement: a survey. Journal of Commercial Banking and Finance, 1, 65-76.

Detry, P. J., \& Grégoire, P. (2001). Other evidences of the predictive power of technical analysis : the moving averages rules on European indexes. In EFMA 2001 Lugano Meetings (pp. 125).

Fama, E. F., \& Blume, M. E. (1966). Filter Rules and Stock Market Trading. The Journal of Business. 39(1), 226-241.

Frost, A. J., \& Prechter, R. R. (2005). Elliot wave principle: key to market behavior. Elliot Wave International.

Garg, M., \& Garg, P. (2013). Ratio by Using Coefficients of Fibonacci Sequence. International Journal of Mathematical Combinatorics, 3, 96-103.

Glezakos, M., \& Mylonas, P. (2003). Technical analysis seems to be a valuable investment tool in the Athens and Frankfurt stock exchanges. European Research Studies, VI(1-2), 163-190.

Heng, F. T. K., Azizan, N. A., \& Yeap, L. W. (2012). Technical trading systems as crystal balls in reducing risk: the Malaysian stock market. International Business Management, 6(2), 140146. doi:10.3923/ibm.2012.140.146

Hudson, R., Dempsey, M., \& Keasey, K. (1996). A note on the weak form efficiency of capital markets: The application of simple technical trading rules to UK stock prices - 1935 to 1994. Journal of Banking and Finance, 20, 1121-1132.

Hung, N. H., \& Zhaojun, Y. (2013). Profitability of applying simple moving average trading rules for the Vietnamese stock market. Journal of Business \& Management, 2(3), 22-31.

Isakov, D., \& Hollistein, M. (1999). Application of simple technical trading rules to Swiss stock prices: Is it profitable ? Financial Markets and Portfolio Management, 13(1), 9-26.

James, F. E. (1968). Monthly moving averages-an effective investment tool? Journal of Financial and Quantitative Analysis, 3(3), 315-326. 
Lai, M. M., Balachandler, K. G., \& Nor, F. mat. (2007). An examination of the random walk model and technical trading rules in the Malaysian stock market. Malaysian Accounting Review, 6(2), 99-121.

Lam, K. S. K., Yeung, H. F., \& Cheung, W. (2007). The profitability of simple technical trading strategies: the case of Hong Kong. In 20th Australasian Finance \& Banking Conference.

Lebaron, B. (2000). The stability of moving average technical trading rules on the Dow Jones Index. Derivatives Use, Trading and Regulation, 5(4), 324-338.

Lubnau, T., \& Todorova, N. (2014). Technical trading revisited: evidence from the asian stock markets. Corporate Ownership \& Control, 11(2), 511-532.

McKenzie, M. D. (2007). Technical trading rules in emerging markets and the 1997 Asian Currency Crises. Emerging Markets Finance and Trade, 43(4), 46-73.

Mills, T. C. (1997). Technical analysis and the London Stock Exchange: Testing trading rules using the FT30. International Journal of Finance \& Economics, 2, 319-331.

Muhannad A. Atmeh, \& Ian M. Dobbs. (2006). Technical analysis and the stochastic properties of the Jordanian stock market index return. Studies in Economics and Finance, 23(2), 119-140.

Nison, S. (2001). Japanese candlestick charting techniques: a contemporary guide to the ancient investment techniques of the Far East. Penguin.

Ratner, M., \& Leal, R. (1999). Tests of technical trading strategies in the emerging equity markets of Latin America and Asia. Journal of Banking \& Finance, 23, 1887-1905.

Ready, M. J. (2002). Profits from technical trading rules. Financial Management, 31(3), 43-61.

Zhu, Y., \& Zhou, G. (2009). Technical analysis: An asset allocation perspective on the use of moving averages. Journal of Financial Economics, 92, 519-544.

Corresponding Author: Kelvin Lee Yong Ming can be contacted at

kelvinklym910104@gmail.com 